\title{
CHEMICAL OXIDATION OF POLYCYCLIC AROMATIC HYDROCARBONS IN WATER BY FERRATES(VI)
}

\begin{abstract}
Polycyclic aromatic hydrocarbons (PAHs) are a common part of the environment where they come from burning fossil fuels (through an incomplete combustion process). From a toxicological point of view, PAHs are considered to be carcinogens with a mutagenic and teratogenic effect. On the other hand, ferrates are generally believed to be the ideal chemical agent for water treatment due to their strong oxidation potential. Herein, the efficiency of degradation of PAHs (with the special emphasis on $\mathrm{B}[\mathrm{a}] \mathrm{P}$ ) by ferrates under laboratory conditions was studied. The formation of degradation products was also considered. For this, two types of ferrates were used and both of them efficiently degraded $\mathrm{B}[\mathrm{a}] \mathrm{P}$. When comparing ferrates that were bought from a Czech and USA company, no significant changes in terms of $\mathrm{B}[\mathrm{a}] \mathrm{P}$ degradability were observed. It was determined that the degradation efficiency of PAHs by ferrates was dependent on their molecular weight. Two and three cyclic PAHs have been completely degraded within 30 minutes, whereas five (and more) cyclic PAHs, only partially. The results obtained with ferrates were compared to the ones obtained with a classical oxidizing agent $-\mathrm{KMnO}_{4}$. In a qualitative test to detect degradation products of PAHs, two were identified, namely fluoren-9-one derived from fluorene and acentaphthylene, formed from acenaphthene.
\end{abstract}

Keywords: polycyclic aromatic hydrocarbons, benzo[a]pyrene, ferrate, degradability, spiked water, oxidizing agent

\section{Introduction}

There is a wide range of homocyclic and heterocyclic derivatives of PAHs that contain nitrogen, oxygen or sulphur atoms in their aromatic structure. This large group, together with PAHs, is referred to as polycyclic aromatic compounds (PACs) [1].

16 PAHs $\left(\mathrm{EPA}_{16}\right)$ with a star $(*)$ and, according to the USEPA (Environmental Protection Agency), are included among the priority pollutants [2]. Dangerous compounds were selected by European Union (EU) for monitoring [3-5], fluoranthen, however, was recently removed [6].

A significant amount of PAHs arises from incomplete combustion of fossil fuels and other organic substances such as coal and wood combustion, the use of combustion engines, and the production of heat and electricity [7]. Motor vehicle emissions can contribute up to a $35 \%$ increase in PAH intake in developing countries [8].

PAHs also arise when food, especially meat products and fish are baked, fried, toasted or grilled due to the incomplete combustion or thermal decomposition (pyrolysis) of

\footnotetext{
${ }^{1}$ Laboratory of Instrumental Chemical Analysis, Institute for Nanomaterials, Advanced Technologies and Innovations, Technical University of Liberec, Bendlova 1409/7, 46117 Liberec 1, Czech Republic

*Corresponding author: barbora.antosova@tul.cz
} 
organic material) [9]. High levels of PAHs may contain oil and coal extracts, including asphalt [10] and creosote [11], used as preservatives for wood. PAHs enter the environment as air pollutants and over time they get into water, soil, sediment and living organisms [12]. Forest fires, volcanic eruptions and soil metabolism (especially perylene) are the largest natural resources of them [13].

USEPA and the World Health Organization (WHO) have selected 16 "priority pollutants" from the PAH group (their structures are shown in Figure 1). The International Agency for Research on Cancer (IARC) has assessed the carcinogenic risk for $49 \mathrm{PAHs}$ with regard to the results of epidemiological and animal studies. 3 PAHs of Class 2A were identified as likely carcinogens: benzo[a]anthracene, benzo[a]pyrene and dibenz[a,h]anthracene; another 12 PAHs were classified as potential carcinogens, class 2B: benzo[b]fluranthen, benzo[j]fluoranthene, benzo[k]fluoranthene and indeno[1,2,3-cd]pyrene. Other PAHs, which are the priority pollutants, were categorised as class 3, assigned to compounds that cannot be classified (tests were not sufficiently conclusive to exclude or demonstrate carcinogenicity) [12]. In Europe, legislation on air protection focuses primarily on the control of benzo[a]pyrene (annual target level of $1 \mathrm{ng} / \mathrm{m}^{3}$ ), as this compound exhibits the highest toxic load from all airborne PAHs $[14,15]$.
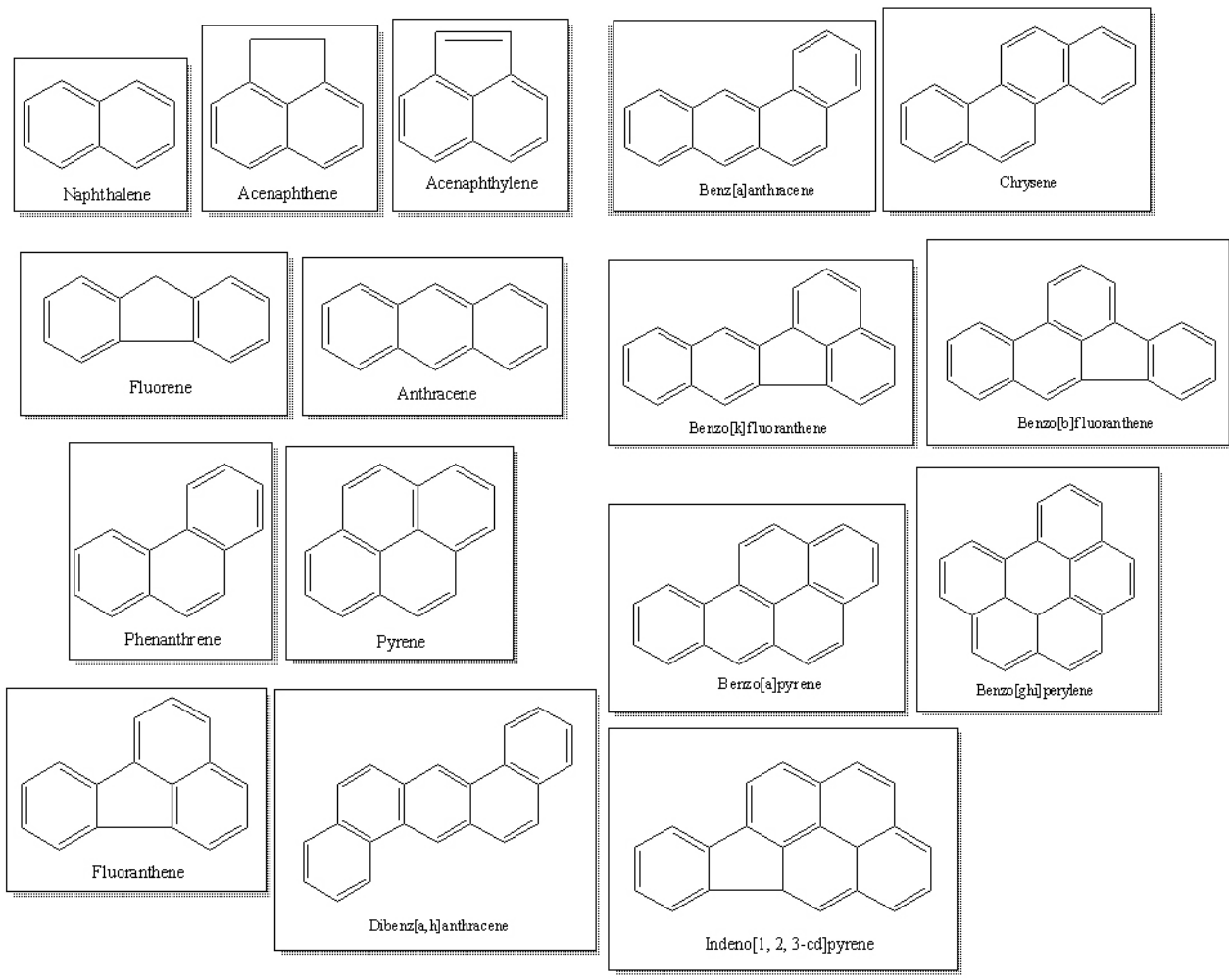

Fig. 1. Structures of the 16 PAHs on the USEPA priority pollutant list

The physical properties of selected PAHs are shown in Table 1. 
Physical properties of selected PAHs $[16,17]$

\begin{tabular}{|c|c|c|c|c|c|c|c|}
\hline \multirow{3}{*}{ Substance } & \multicolumn{7}{|c|}{ At $25^{\circ} \mathrm{C}$} \\
\hline & MW & MP & BP & $\mathbf{V P}$ & $\mathbf{S}$ & \multirow{2}{*}{$\log K_{o w}$} & \multirow{2}{*}{$\log K_{o c}$} \\
\hline & [g/mol] & {$\left[{ }^{\circ} \mathbf{C}\right]$} & {$\left[{ }^{\circ} \mathbf{C}\right]$} & {$[\mathbf{P a}]$} & {$\left[\mathrm{g} \mathrm{m}^{-3}\right]$} & & \\
\hline Naphthalene (NAP) & 128 & 31 & 218 & 10.4 & 31 & 3.37 & 3.11 \\
\hline Acenaphthylene (ACE) & 152 & 96 & 278 & $3 \cdot 10^{-1}$ & 38 & 3.92 & 3.79 \\
\hline Acenaphthene (ACY) & 154 & 92 & 265 & $9 \cdot 10^{-1}$ & 16 & 4.00 & 3.83 \\
\hline Fluorene (FLU) & 166 & 116 & 295 & $9 \cdot 10^{-2}$ & 1.9 & 4.18 & 4.15 \\
\hline Anthracene (ANC) & 178 & 216 & 340 & $1 \cdot 10^{-3}$ & 0.045 & 4.54 & 4.41 \\
\hline Phenanthrene (PHN) & 178 & 101 & 339 & $2 \cdot 10^{-2}$ & 1.1 & 4.57 & 4.22 \\
\hline Pyrene (PYR) & 202 & 111 & 375 & $1.2 \cdot 10^{-3}$ & 0.26 & 5.22 & 4.74 \\
\hline Fluoranthene (FLA) & 202 & 156 & 360 & $6 \cdot 10^{-4}$ & 0.13 & 5.18 & 4.82 \\
\hline Benz[a]anthracene (B[a]A) & 228 & 160 & 435 & $2.8 \cdot 10^{-5}$ & 0.011 & 5.91 & 5.66 \\
\hline Chrysene (CHY) & 228 & 255 & 448 & $5.7 \cdot 10^{-7}$ & & 1.65 & 5.37 \\
\hline Benzo[b]fluoranthene $(\mathrm{B}[\mathrm{b}] \mathrm{F})$ & 252 & 168 & 481 & - & 0.0015 & 5.80 & 5.89 \\
\hline Benzo[k]fluoranthene $(\mathrm{B}[\mathrm{k}] \mathrm{F})$ & 252 & 217 & 481 & $5.2 \cdot 10^{-8}$ & 0.0008 & 6.00 & 5.89 \\
\hline Benzo[a]pyrene $(\mathrm{B}[\mathrm{a}] \mathrm{P})$ & 252 & 175 & 495 & $7.0 \cdot 10^{-7}$ & 0.0038 & 6.04 & 5.71 \\
\hline Indeno[1,2,3-cd]pyrene (IND) & 276 & 164 & 536 & - & 0.00019 & 6.58 & 6.14 \\
\hline Benzo[g,h,i]perylene (B[ghi]P) & 276 & 277 & & - & 0.00026 & 6.50 & - \\
\hline Dibenz[a,h]anthracene (D[ah]A & 278 & 267 & 524 & $3.7 \cdot 10^{-10}$ & 0.0006 & 6.75 & 5.97 \\
\hline
\end{tabular}

MW - molecular weight, MP - melting point, BP - boiling point, VP - vapour pressure of the solid, S - water solubility, $K_{o w}$ - octanol/water partition coefficient, $K_{o c}$ - soil partition coefficient

The vapour pressure of PAHs decreases by more than 11 orders of magnitude with the increasing number of condensed benzene rings. Larger PAHs (with three and four rings) are distributed between the gaseous and solid phases in the environment. PAHs with five or more aromatic rings are found to be almost exclusively linked to a particle or solid phase [18]. The solubility of PAH in water with 2 to 6 rings decreases by 5 orders with the increase of their molecular weight. For this reason, two- and three-ring PAHs are likely to be found in the aqueous phase, in comparison to higher molecular weight PAHs that tend to associate with the dissolved organic matter (DOM) and solid phase such as soot [19]. The soil/water partition coefficient $\left(K_{o c}\right)$ is the ability of the substance to pass from water to the organic constituent of the soil. The $\log K_{o c}$ value is relatively high for PAHs, indicating a strong tendency for PAHs to be trapped in soils and sediments, although originally most are scattered in the atmosphere [20]. Due to the low solubility of PAHs in water they usually can be found at extremely low concentrations. The typical groundwater interface is 10 to $50 \mathrm{ng} / \mathrm{dm}^{3}$, and for surface waters it is 50 to $250 \mathrm{ng} / \mathrm{dm}^{3}$ [21].

These compounds can occur in the gas phase and in conjunction with atmospheric particles, particularly in the fraction of submicron particles, which promotes their transport over long distances. Both gaseous and particulate PAHs are deposited in dry and terrestrial ecosystems by dry deposition processes (gas absorption, gravity deposition, swirling diffusion) and precipitation excretion, which include both droplet formation and cloud capture. Therefore, atmospheric deposition of PAH is a significant source of PAHs at local, regional and global scale, which is responsible for the presence of these compounds in remote areas and open oceans far from their emission sources [22].

Nitro- and oxy-PAHs are reaction products of PAHs and reactive components (e.g. oxides of nitrogen, ozone) in the combustion chamber and atmosphere [23]. It is known that many PAHs and nitro-PAHs found in the air have mutagenic and carcinogenic effects and may pose a risk to human health [24]. For example, while testing Salmonella 
typhimurium (strain TA98) without the presence of exogenous metabolizing enzymes (i.e. hepatic S9 fraction) it was found that 1-nitropyrene, 1,3-dinitropyrene, 1,6-dinitropyrene and 1,8-dinitropyrene were 200, 6.3E4, 8.0E4 and 1.1E5 times more mutagenic than bezo[a]pyrene $(+\mathrm{S} 9)$. This intense sensitivity of $S$. typhimurium to nitro-PAHs is attributed to the presence of native nitroreductase enzymes that initiate the metabolism of nitro-PAH to their final mutagenic metabolites - arylhydroxylamine [23, 25]. Mutagenic oxy-PAHs include quinones of pyrene and benzo[a]pyrene, some ketones and pyrene-3,4-dicarboxylic anhydride.

Laboratory-grown organisms kept in sediments from sites contaminated with PAH are subjected to photoactivated toxicity. Determined toxicity depends both on the intake of PAH (or other contaminants) and on UV exposure [26]. Photosensitive sediment toxicity was confirmed by Monson et al. [27] in in situ tests performed at sites where contaminated sediments were collected by Ankley et al. [28].

Iron salts are known only in the ferrous (Fe(II) and the ferric forms (Fe(III)); the higher oxidized forms $\mathrm{Fe}(\mathrm{IV}), \mathrm{Fe}(\mathrm{V})$ and $\mathrm{Fe}(\mathrm{VI})$ give unstable compounds called ferrates. Ferrates are more stable at low temperatures and higher $\mathrm{pH}$ [29]. The ferrate(VI) ion has a formula $\mathrm{FeO}_{4}{ }^{2-}$ and its aqueous solution has a typical red-violet colour [30]. Ion $\mathrm{FeO}_{4}{ }^{2-}-$ has a tetrahedral structure similar to its solid-state geometry and four covalent $\mathrm{Fe}-\mathrm{O}$ bonds. Potassium ferrate is insoluble in common organic solvents. It can be suspended in ether, chloroform, benzene, alcohols (to $20 \%$ water) and other solvents without rapid decomposition.

Since there is a continuous search for appropriate water treatment methods [31-36], ferrates emerged as a potential alternative for conventional processes due to several advantages. For example, they are strong oxidants throughout the whole $\mathrm{pH}$ range [37]. They have a higher oxidation-reduction potential than $\mathrm{Mn}(\mathrm{VII}) / \mathrm{Mn}(\mathrm{IV}), \mathrm{Cr}(\mathrm{VI}) / \mathrm{Cr}(\mathrm{III})$ (Table 2) or commonly used oxidants (e.g. ozone, hydrogen peroxide, chlorine, perchlorate, hypochlorite) and can be therefore applied for remediation of drinking and wastewater [38, 39]. Ferrates can be photoreduced to $\mathrm{Fe}(\mathrm{V})$ to produce an even stronger oxidant than $\mathrm{Fe}(\mathrm{VI})$ [40]. Ferrate(VI) is capable of quickly oxidizing many toxic pollutants including chemical weapons [37, 41] however, according to our knowledge, it was never used for oxidizing highly toxic PAHs.

Reduction potential of $\mathrm{Cr}(\mathrm{VI}), \mathrm{Mn}(\mathrm{VII})$ and $\mathrm{Fe}(\mathrm{VI})$ in aqueous solutions [37]

\begin{tabular}{|c|c|c|c|}
\hline Acidic medium & $\boldsymbol{E}^{\mathbf{0}}[\mathbf{V}]$ & Basic medium & $\boldsymbol{E}^{\mathbf{0}}[\mathbf{V}]$ \\
\hline $\mathrm{Cr}_{2} \mathrm{O}_{7}{ }^{2-} / \mathrm{Cr}^{3+}$ & 1.33 & $\mathrm{CrO}_{4}{ }^{2-} / \mathrm{Cr}(\mathrm{OH})_{3}$ & -0.12 \\
\hline $\mathrm{MnO}_{4}{ }^{-} / \mathrm{MnO}_{2}$ & 1.67 & $\mathrm{MnO}_{4} / \mathrm{MnO}_{2}$ & 0.56 \\
\hline $\mathrm{FeO}_{4}{ }^{2-} / \mathrm{Fe}^{3+}$ & 2.20 & $\mathrm{FeO}_{4}{ }^{2-} / \mathrm{Fe}(\mathrm{OH})_{3}(\mathrm{~s})$ & 0.72 \\
\hline
\end{tabular}

The SEKM (in Czech: system evidence kontaminovanych mist) system, managed by the Ministry of the Environment of the Czech Republic, records a total of 524 sites contaminated by PAHs in the Czech Republic, of which no corrective action has yet been taken on 117 sites [42]. This was the reason why PAHs (and in particular B[a]P) were chosen as model pollutants for testing the decontamination efficiency of ferrates.

In this study, ferrates were used for the removal of PAHs, including the most toxic $\mathrm{B}[\mathrm{a}] \mathrm{P}$, from the spiked water. A highly pure ferrate purchased from Sigma-Aldrich has been tested but because it was removed from the market - we have conducted a search for 
a suitable alternative to it (with the same or at least similar properties). For comparison, in addition to commercially obtained ferrate samples, the potassium permanganate was used. In addition, several reaction intermediates were found and reported herein.

\section{Materials and methods}

\section{Chemicals}

Highly pure potassium ferrate (> $90 \% \mathrm{~K}_{2} \mathrm{FeO}_{4}$, from Sigma-Aldrich (SA)) and potassium ferrate (> $55 \% \mathrm{~K}_{2} \mathrm{FeO}_{4}$, from Santa Cruz Biotechnology, Inc. (SCB)) were used in this study. Further, another ferrate (LAC 035; produced by Czech company LAC s.r.o.) was used. ICP/OES analysis of the used ferrates is shown in Table 3.

ICP/OES analysis of the used ferrates

Table 3

\begin{tabular}{|c|c|c|c|}
\hline $\begin{array}{l}\text { Concentration of } \\
\text { elements in ferrate } \\
\text { samples }[\mathrm{mg} / \mathrm{kg}]\end{array}$ & SA & SCB & LAC 035 \\
\hline $\mathrm{Ag}$ & $<2.0$ & $<2.0$ & $<2.0$ \\
\hline $\mathrm{Al}$ & $<4.0$ & 8.25 & 226 \\
\hline As & $<4.0$ & $<4.0$ & $<4.0$ \\
\hline $\mathrm{B}$ & $<20.0$ & $<20.0$ & $<20.0$ \\
\hline $\mathrm{Ba}$ & 10.45 & 2.8 & 5.82 \\
\hline $\mathrm{Be}$ & 4.71 & 1.32 & 3.03 \\
\hline $\mathrm{Ca}$ & 14.37 & 35.8 & 233 \\
\hline $\mathrm{Cd}$ & $<2.0$ & $<2.0$ & $<2.0$ \\
\hline Co & $<4.0$ & $<4.0$ & 26.6 \\
\hline $\mathrm{Cr}$ & 1190 & 35.7 & 222 \\
\hline $\mathrm{Cu}$ & $<4.0$ & $<4.0$ & 6.42 \\
\hline $\mathrm{Fe}$ & 323600 & 82230 & 276800 \\
\hline $\mathrm{K}$ & 431300 & 480600 & 450900 \\
\hline $\mathrm{Li}$ & 0.81 & 0.18 & 0.50 \\
\hline $\mathrm{Mg}$ & 1.45 & 5.32 & 206 \\
\hline $\mathrm{Mn}$ & 1830 & 5.05 & 55.2 \\
\hline Mo & $<4.0$ & $<4.0$ & $<4.0$ \\
\hline $\mathrm{Na}$ & 154 & 5015 & 638 \\
\hline $\mathrm{Ni}$ & $<2.0$ & $<2.0$ & 237 \\
\hline $\mathrm{Pb}$ & $<10.0$ & $<10.0$ & $<10.0$ \\
\hline $\mathrm{Sb}$ & $<4.0$ & $<4.0$ & $<4.0$ \\
\hline $\mathrm{Se}$ & $<4.0$ & $<4.0$ & $<4.0$ \\
\hline $\mathrm{Si}$ & 180 & 1202 & 10 \\
\hline $\mathrm{Sn}$ & $<4.0$ & $<4.0$ & 8.50 \\
\hline $\mathrm{Sr}$ & 0.21 & 0.23 & 0.31 \\
\hline $\mathrm{Ti}$ & 0.91 & 0.45 & 218 \\
\hline $\mathrm{Tl}$ & $<4.0$ & $<4.0$ & $<4.0$ \\
\hline $\mathrm{V}$ & $<4.0$ & $<4.0$ & 156 \\
\hline $\mathrm{Zn}$ & 20.2 & $<4.0$ & 12.4 \\
\hline
\end{tabular}

Content of Fe was determined by elementary analysis as $35.7 \%$ (LAC 035). Atomic Absorption Spectrometry analysis specified content of selected heavy metals: $0.0389 \% \mathrm{Cr}$ and $0.034 \% \mathrm{Ni}$ (LAC 035).

Stock ferrate solution was prepared by dissolving different weights (depending on ferrate purity and required final $\mathrm{FeO}_{4}{ }^{2-}$ concentrations) of the solid sample in cooled, tap 
water. Ferrates are highly inhomogeneous and unstable, therefore, precise concentrations cannot be calculated in advance. Final concentrations of the Fe(VI) stock solutions were calculated retrospectively after spectrophotometric measurement. All Fe(VI) stock solutions were prepared just before the experiments (max. 10 minutes before).

Benzo[a]pyrene $\mathrm{C}_{20} \mathrm{H}_{12}$ (purity $99.5 \%, 10 \mathrm{ng} / \mathrm{mm}^{3}$ in Acetonitrile) and PAH-Mix 9 (containing 16 PAHs of $98-99.6 \%$ purity, $10 \mathrm{ng} / \mathrm{mm}^{3}$ in Acetonitrile) were purchased in Ehrenstorfer company.

Supelco PAH Kit 610-N (16 EPA individual PAHs: acenapthene, acenaphthylene, anthracene, benzo[a]anthracene, benzo[a]pyrene, benzo[b]fluoranthene, benzo[k]fluoranthene, benzo[g,h,i]perylene, dibenzo[a,h]anthracene, fluoranthene, fluorene, chrysene, indeno[1,2,3-cd]pyrene, naphthalene, phenanthrene, pyrene).

The internal standard of four isotopically labelled PAHs (ISTD) was added: D8 - naphthalene $12.29 \mu \mathrm{g} / \mathrm{mm}^{3}$, D10 - phenanthrene $100 \mu \mathrm{g} / \mathrm{cm}^{3}$, D12 - chrysene $100 \mu \mathrm{g} / \mathrm{cm}^{3}$, D12 - perylene $100 \mu \mathrm{g} / \mathrm{cm}^{3}$. The ISTD stock solution was prepared by mixing $3 \mathrm{~cm}^{3}$ of Perylene, $1 \mathrm{~cm}^{3}$ of Chrysene, $1 \mathrm{~cm}^{3}$ of Phenanthrene, $3.3 \mathrm{~mm}^{3}$ of Naphthalene and $10 \mathrm{~cm}^{3}$ of Acetone (HPLC grade) in a $20 \mathrm{~cm}^{3}$ vial.

The other chemicals used in the experiments were purchased in the required analytical grade and were used without further purification. These include $\mathrm{Na}_{2} \mathrm{SO}_{3}$ anhydrous p.a., $95 \%$ hexane for HPLC and absolute methanol for LACHNER HPLC, $95 \%$ HPLC for Chromservis s.r.o. and $\mathrm{Na}_{2} \mathrm{SO}_{4}$ anhydrous p.a., $\mathrm{KMnO}_{4}$ p.a. by PENTA; PAHs and benzo[a]pyrene were obtained from Dr. Ehrenstorfer $\mathrm{GmbH}$.

\section{Methods}

Experiments with spiked water with $\mathrm{B}[\mathrm{a}] \mathrm{P}$ were carried out in $250 \mathrm{~cm}^{3}$ reactors. $200 \mathrm{~cm}^{3}$ of tap water, $20 \mathrm{~mm}^{3}$ of $\mathrm{B}[\mathrm{a}] \mathrm{P}$, and the ferrate solution (dose $5 \mathrm{~cm}^{3}, 10 \mathrm{~cm}^{3}$ or in several doses) were dispensed to continuously stirred reactors. The $\mathrm{FeO}_{4}{ }^{2-}$ concentration was measured spectrophotometrically in each experiment. The concentration of $\mathrm{B}[\mathrm{a}] \mathrm{P}$ was $4 \cdot 10^{-3} \mu \mathrm{M}$ (equivalent to $1 \mu \mathrm{g} / \mathrm{dm}^{3}$ ). After a certain period, the reaction was stopped by the addition of $100 \mathrm{~mm}^{3}$ of $1 \mathrm{M} \mathrm{Na}_{2} \mathrm{SO}_{3}$ solution. The solutions were extracted with $4 \mathrm{~cm}^{3}$ of heptane and $2 \mathrm{~cm}^{3}$ of methanol (shaking for $60 \mathrm{~min}$ at horizontal shaker) the same day. One $\mathrm{cm}^{3}$ was taken from each extract and $10 \mathrm{~mm}^{3}$ of ISTD stock solution was added to the GC-MS/MS analysis. Each set of samples contained control and base samples. Control samples were processed in the same way as experimental samples, without the addition of $\mathrm{B}[\mathrm{a}] \mathrm{P}$. The base samples contained the standing water tapped $\mathrm{B}[\mathrm{a}] \mathrm{P}$ without the addition of ferrate. Experiments were performed in triplicate at ambient temperature.

Experiments with water-doped PAHs were performed in $250-\mathrm{cm}^{3}$ reactors. $200 \mathrm{~cm}^{3}$ of standing tap water, $20 \mathrm{~mm}^{3}$ of PAH-Mix 9 and finally the ferrate solution $\left(5 \mathrm{~cm}^{3}\right)$ were dispensed to the continuously stirred reactors. The concentrations of each PAH in each reactor were $4 \cdot 10^{-3} \mu \mathrm{M}$ (i.e., $1 \mu \mathrm{g} / \mathrm{dm}^{3}$ ). The $\mathrm{FeO}_{4}{ }^{2-}$ concentration was measured spectrophotometrically in each experiment. The dose of $\mathrm{KMnO}_{4}$ was chosen to suitably correspond to the added ferrate moles. After a certain period, the reaction was stopped by the addition of $100 \mathrm{~mm}^{3}$ of $1 \mathrm{M} \mathrm{Na}_{2} \mathrm{SO}_{3}$ solution. A mixture of $4 \mathrm{~cm}^{3}$ of hexane and $2 \mathrm{~cm}^{3}$ of methanol (shaking for $60 \mathrm{~min}$ at horizontal shaker) was used as the extraction agent. One $\mathrm{cm}^{3}$ was taken from each extract and $10 \mathrm{~mm}^{3}$ of ISTD stock solution was added to the GC-MS/MS analysis. Each set of samples contained control and base samples. The control, base and experimental samples were processed in the same way as mentioned in the previous section. 
An experiment to determine degradation products of PAHs was performed in two sets of 17 vials of $20 \mathrm{~cm}^{3}$ volume with cap and PTFE coated septa. $10 \mathrm{~cm}^{3}$ of demi water was added to all 34 vials. Then several crystals of 16 individual PAHs were added into individual vials (approx. $1 \mathrm{mg}$ ). Samples were shaken for 1 hour on horizontal shaker. This was followed by addition of $5 \mathrm{~cm}^{3}$ of ferrate SA stock solution (ferrate set of vials) or $5 \mathrm{~cm}^{3}$ of demi water (control set of vials). The concentration of $\mathrm{FeO}_{4}{ }^{2-}$ in the stock solution was measured spectrophotometrically and corresponded to $1.36 \mathrm{mM}$. The reaction time was 120 minutes. After this time, the individual filtrates were extracted with $5 \mathrm{~cm}^{3}$ of hexane (shaking for $30 \mathrm{~min}$ at a horizontal shaker). Moreover, one blank was also assigned a sample without PAHs or ferrates. Extracts were measured by GC-MS (full scan mode of operation).

\section{Analytical methods}

Gas chromatography in conjunction with mass spectrometry is currently a common analytical method that combines the high capillary gas chromatographic separation capability with detection highly specific for the given analyte while allowing information on the structure of unknown substances. For measurements, a Thermo Trace 1310 gas chromatograph with a TSQ 8000 mass spectrometer with triple quadrupole (GC-MS/MS) was used. Automatic dosing of the prepared samples was performed with a $1 \mathrm{~mm}^{3} \mathrm{PAL}$ LHX-xt autosampler. Fe(VI) concentrations were determined using a SHIMADZU UV-1601 UV/VIS absorption spectrometer with a molar absorbance of $1150 \mathrm{M}^{-1} \mathrm{~cm}^{-1}$ at $505 \mathrm{~nm}[43]$.

Most PAHs show fluorescent properties after excitation at their characteristic wavelengths, allowing their selective detection in different environmental samples. Fluorescence measurements do not interact nor destroy samples, and by-products are not generated during measurement [44]. Herein we have compared GC analytical technique with the fluorescent one in order to check the reliability of the GC-MS/MS method (Fig. 2). The fluorescence wavelength at the measurement of the $\mathrm{B}[\mathrm{a}] \mathrm{P}$ concentration for excitation and emission was selected at 297 and $405 \mathrm{~nm}$, respectively [45, 46]. The Tecan Spark Microplate Reader Spectrofluorimeter was used for measurement.

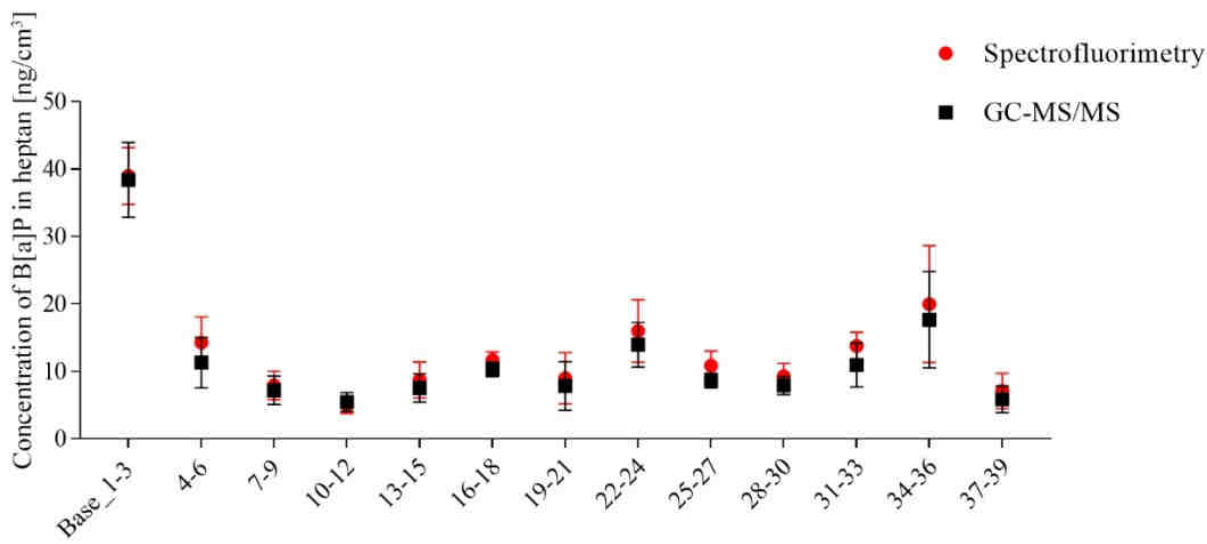

Fig. 2. Comparison of spectrofluorometric and GC-MS/MS techniques with B[a]P (mean + standard deviation contaminated samples). Base (1-3) - no ferrate addition, only dose $4 \cdot 10^{-3} \mu \mathrm{M}$ of $\mathrm{B}[\mathrm{a}] \mathrm{P}$ 
Comparison of two detection methods to determine the exact $\mathrm{B}[\mathrm{a}] \mathrm{P}$ concentration, spectrofluorimetric method and GC-MS/MS on 39 samples showed very good match in the results (Fig. 2) [44] and it could be therefore inferred that the GC-MS/MS method is highly reliable and can be used in this study for quantitative determination of PAHs.

\section{Results and discussion}

\section{$B[a] P$ reactivity with ferrate with spiked water}

Several ferrate species at different doses were applied to a system containing a tap water with $\mathrm{B}[\mathrm{a}] \mathrm{P}$. Based on several studies demonstrating the degradation effects of ferrates on organic pollutants, it was assumed that this substance should be completely removed from the reactor $[37,41,47]$. Complete $\mathrm{B}[\mathrm{a}] \mathrm{P}$ removal occurred only with the application of highly pure ferrate SA. For the other ferrates there was only a partial decrease of $\mathrm{B}[\mathrm{a}] \mathrm{P}$ concentration in the reactors (Figs. 3-5).

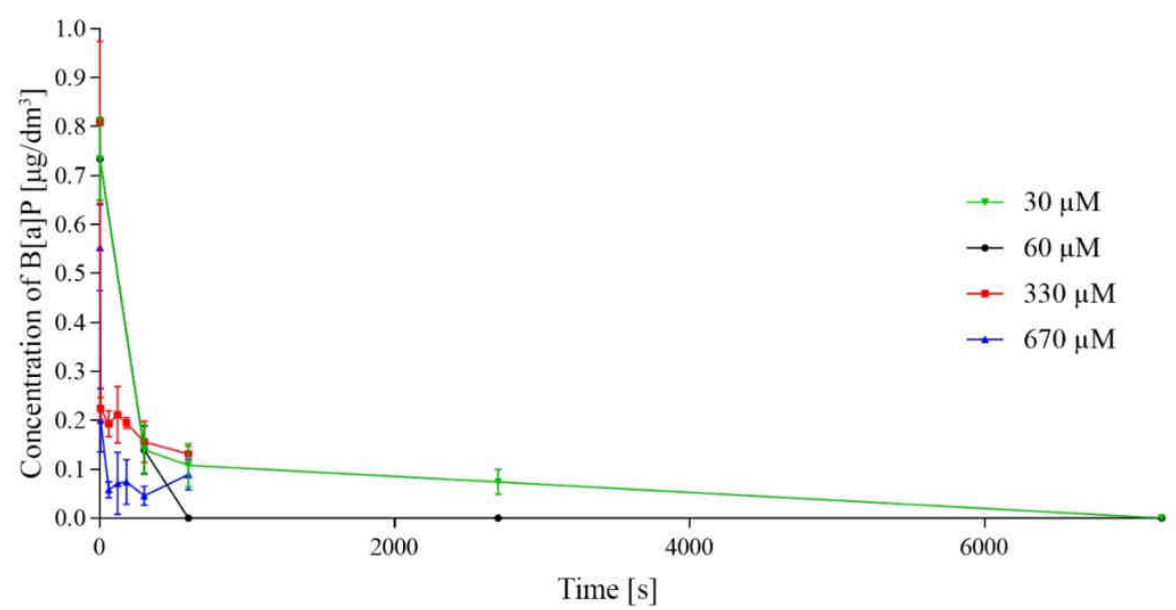

Fig. 3. Comparison of various ferrate SA doses for the removal of $\mathrm{B}[\mathrm{a}] \mathrm{P}$ (mean + standard deviation). Time 0 (base) - no ferrate addition, only dose $4 \cdot 10^{-3} \mu \mathrm{M}$ B [a]P

When comparing ferrates SA and SCB at doses of about $30 \mu \mathrm{M}$, the $\mathrm{B}[\mathrm{a}] \mathrm{P}$ concentration dropped below the detection limit $\left(0.02 \mu \mathrm{g} / \mathrm{dm}^{3}\right)$ in both ferrate treatments up to 120 hours. When the ferrate dose was increased two times, the complete degradation of $\mathrm{B}$ [a]P was observed already after 10 minutes of reaction. Ferrate SA in the concentration of $60 \mu \mathrm{M}$, was able to completely remove $\mathrm{B}[\mathrm{a}] \mathrm{P}$ after 10 minutes.

The cheaper, but equally good Czech ferrate alternative (LAC 035) achieved similar results in the degradation of $\mathrm{B}[\mathrm{a}] \mathrm{P}$. Neither of the tested ferrate samples could degrade $\mathrm{B}$ [a]P to the USEPA [48] limit values. The best degradation attempt was achieved with a single dose of $60 \mu \mathrm{M}$ ferrate, whereas LAC ferrate responded to degradation $\mathrm{B}$ [a]P better than SCB ferrate.

Furthermore, repeated additions of LAC 035 and SCB ferrates ( 5 times the same dose after 1 minute) did not cause better degradation of the contaminant (what was expected) but rather slightly inhibited the degradation of $\mathrm{B}[\mathrm{a}] \mathrm{P}$ in the reactor compared to single dose ferrate (Fig. 6). 


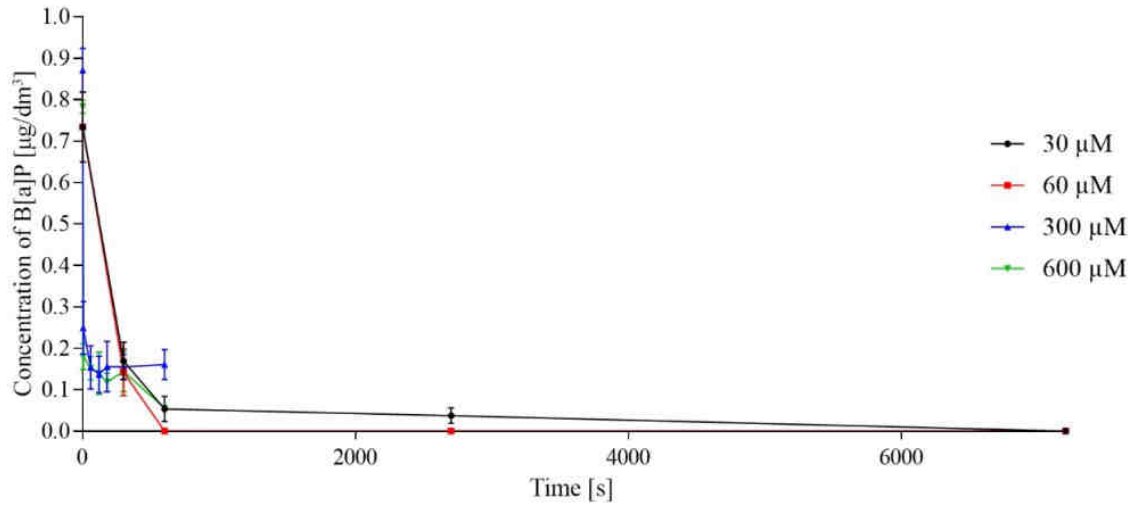

Fig. 4. Comparison of various ferrate SCB doses for the removal of B[a]P (mean + standard deviation). Time 0 (base) - no ferrate addition, only dose $4 \cdot 10^{-3} \mu \mathrm{M} \mathrm{B}[\mathrm{a}] \mathrm{P}$

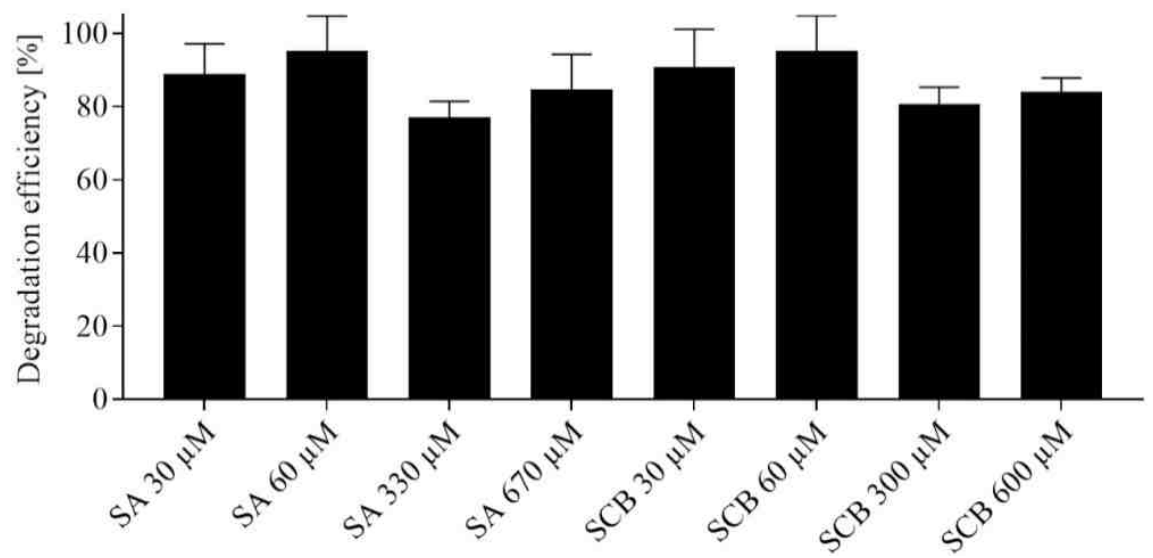

Fig. 5. Removal efficiency of B[a]P by various doses of two different ferrates after 120 minutes



Fig. 6. Concentration $\mathrm{B}[\mathrm{a}] \mathrm{P}$ after 5 minutes of decontamination with different doses of two commercial ferrates (mean + standard deviation). Base - no ferrate addition, only dose $4 \cdot 10^{-3} \mu \mathrm{M} \mathrm{B}[\mathrm{a}] \mathrm{P}$ 


\section{PAHs reactivity with ferrate spiked water}

Two types of ferrate were tested in a system containing tap water to degrade 16 PAHs (Fig. 7).

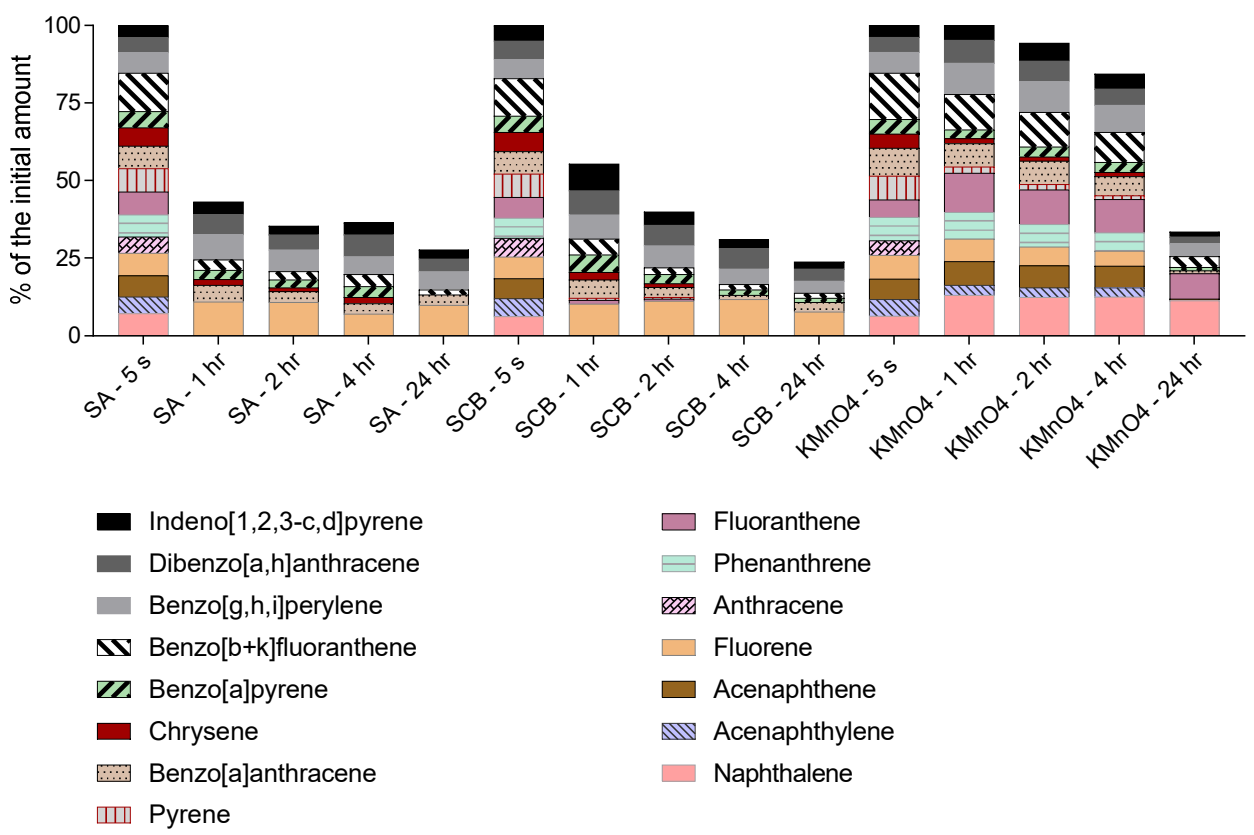

Fig. 7. Concentration of individual PAHs after addition of SA and SCB ferrates and $\mathrm{KMnO}_{4}$. Base - no ferrate addition, only dose of PAHs $\left(4 \cdot 10^{-3} \mu \mathrm{M}\right)$ corrected brackets in in the graph

Some studies on water oxidation showed that $\mathrm{Fe}(\mathrm{VI})$ could remove several organic pollutants (for example benzene, phenol, naphthalene, nitrilotriacetic acid) [49, 50]. For comparison, strong oxidizing agent, as a matter of fact, having several similar properties with ferrates - potassium permanganate, was also included.

PAHs with 2-3 aromatic rings were degraded by both ferrates within 30 minutes. Fluorene was found to be the most recalcitrant PAH and was completely removed only by using the $\mathrm{KMnO}_{4}$ after 24 hours. Four circular PAHs, fluoranthene and pyrene were degraded by ferrate SA within 45 minutes and chrysene after 6 hours; The SCB removed these three PAHs after 180 minutes. The only PAH in this group that failed to be completely removed was $\mathrm{B}[\mathrm{a}] \mathrm{A}$, the residual concentration of which remained in the reactors using both types of ferrates. For PAH with 5 or more cycles, only a partial decrease in concentration was observed, with $\mathrm{B}[\mathrm{b}+\mathrm{k}] \mathrm{F}$ by $11.5 \%$; $\mathrm{B}[\mathrm{a}] \mathrm{P}-8.7 \%$; IND - $15.1 \%$; $\mathrm{B}$ [g,h,i]P - $24.8 \%$ and D[a,h]A by $27.3 \%$ for SCB ferrate. These results correspond to the conclusions of several authors, which foreseen the increase of PAHs resistance to degradation with increase of the PAHs molecular weight $[45,46,51,52]$. Better results have been achieved with the SA ferrate, where the complete degradation of the most toxic $\mathrm{B}$ [a]P occurred after 24 hours. For other PAHs with 5 aromatic rings, the concentration 
decreased of $\mathrm{B}[\mathrm{b}+\mathrm{k}] \mathrm{F}$ by $11.7 \%$; IND - $21.5 \%$; $\mathrm{B}[\mathrm{g}, \mathrm{h}, \mathrm{i}] \mathrm{P}-41.8 \%$ and $\mathrm{D}[\mathrm{a}, \mathrm{h}] \mathrm{A}$ by $28.8 \%$. The use of the $\mathrm{KMnO}_{4}$ oxidizing agent was effective after 24 hours and is more suitable for PAHs with a lower molecular weight i.e.: acenaphthylene, fluorene, anthracene, phenathrene ( 3 cycles), pyrene, chrysene (4 cyclic). Concentration of PAHs in the reactors after 24 hours in presence of two types of ferrates and $\mathrm{KMnO}_{4}$ is shown in Table 4.

Table 4

Concentrations of PAHs in the reactors after 24 hours in presence of two types of ferrates and $\mathrm{KMnO}_{4}$ (control - $100 \%)$

\begin{tabular}{|c|c|c|c|}
\hline \multirow{2}{*}{$\begin{array}{c}\text { Individual tested PAHs } \\
\text { contained in the mixture }\end{array}$} & \multicolumn{3}{|c|}{ Initial concentration [\%] } \\
\cline { 2 - 4 } & KMnO $_{\mathbf{4}}$ & $\mathbf{S A}$ & SCB \\
\hline Naphthalene & 11 & $<1$ & $<1$ \\
\hline Acenaphthylene & $<1$ & $<1$ & $<1$ \\
\hline Acenaphthene & $<1$ & $<1$ & $<1$ \\
\hline Fluorene & $<1$ & 10 & 8 \\
\hline Anthracene & $<1$ & $<1$ & $<1$ \\
\hline Phenanthrene & $<1$ & $<1$ & $<1$ \\
\hline Fluoranthene & 8 & $<1$ & $<1$ \\
\hline Pyrene & $<1$ & $<1$ & $<1$ \\
\hline Benzo[a]anthracene & $<1$ & 3 & 3 \\
\hline Chrysene & $<1$ & $<1$ & $<1$ \\
\hline Benzo[a]pyrene & $<1$ & $<1$ & 1 \\
\hline Benzo[b+k]fluoranthene & 4 & 2 & 2 \\
\hline Benzo[g,h,i]perylene & 4 & 6 & 4 \\
\hline Dibenzo[a,h]anthracene & 2 & 4 & 4 \\
\hline Indeno[1,2,3-c,d]pyrene & 1 & 3 & 2 \\
\hline
\end{tabular}

\section{Analysis of degradation products - qualitative experiment}

It is known that some intermediates and by-products produced during the oxidation of PAHs, especially oxy-PAHs, have toxic and mutagenic effects. Some may be even more toxic than the original parent compound [53]. Therefore, it was necessary to find out what products are produced during the degradation of PAHs using ferrates.

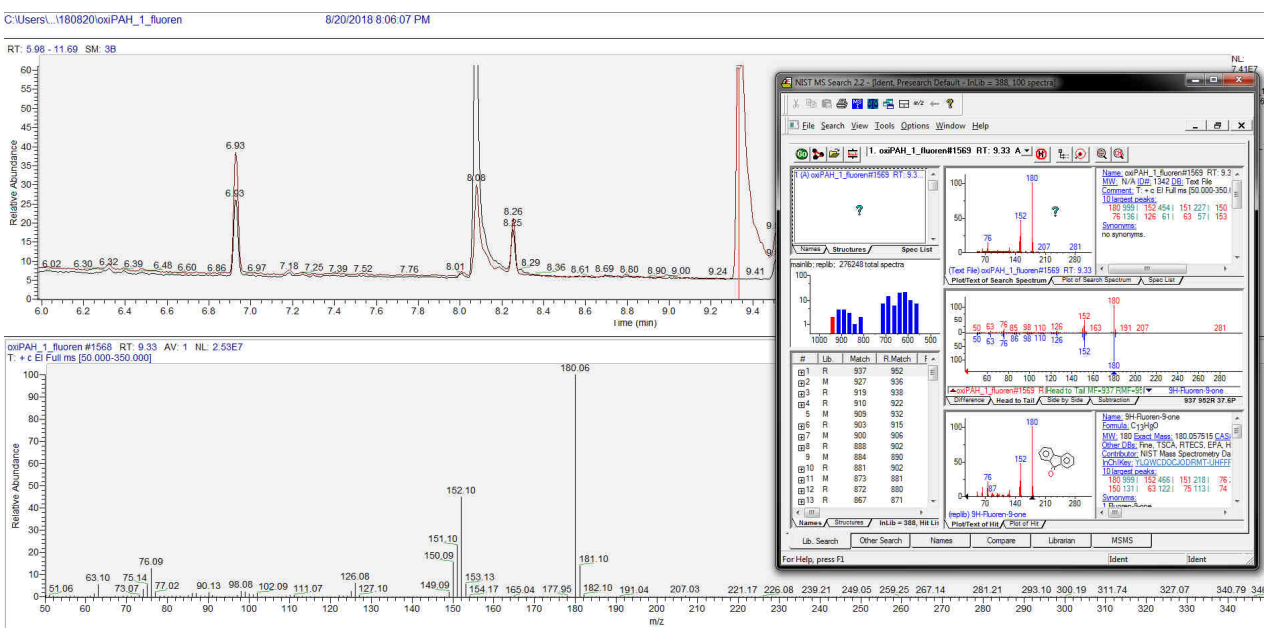

Fig. 8. GC-MS full scan of the product of fluorene oxidation 
As described for fluorene degradation [53], one of the major metabolites is 9H-fluoren-9-one. In our experiments, 9H-fluoren-9-one has been determined as the major and the most stable oxidation product (Fig. 8). Also, acenaphthylene was identified (GC-MS, NIST Library) as transformation product of acenaphthene.

Other PAH oxidation by-products included in the experiments were not detected by GC-MS/MS.

\section{Conclusion}

This paper summarizes the use of ferrates for removal of PAHs (especially B[a]P) in water phase. It has been shown that ferrates are able to degrade PAHs, as well as $\mathrm{B}[\mathrm{a}] \mathrm{P}$ itself, whereas the resistance of each PAHs increases with their molecular weight. The effectiveness of the degradation depends both on the quality of the ferrate and the way/quantity that it is dosed.

When comparing ferrates SA and SCB at a dose of $30 \mu \mathrm{M}$ per reactor, the two ferrates were able to remove all $\mathrm{B}[\mathrm{a}] \mathrm{P}$ after 120 minutes. If the ferrate dose was increased twice, $\mathrm{B}$ [a]P was removed after 10 minutes.

Appropriate alternatives (Czech and foreign) for commonly used ferrates (that possess similar properties) have been found. The Czech Republic ferrate (LAC 035) degraded $\mathrm{B}[\mathrm{a}] \mathrm{P}$ better than ferrate SCB at single dose of $60 \mu \mathrm{M}$. Repeated additions of these ferrates did not improve degradation of $\mathrm{B}[\mathrm{a}] \mathrm{P}$ but slightly inhibited.

In the presence of ferrate SA, the residual concentration of PAHs after 24 hours was highest for fluorene and amounted to $10 \%$ of the initial amount. Using the classic oxidant $\mathrm{KMnO}_{4}$, the residual concentration of PAHs after 24 hours was highest for naphthalene, $11 \%$ of the initial amount. Several oxidation products of PAHs were found i.e.: fluoren-9-one that was generated from fluorene, and acenaphthylene formed from acenaphthene.

\section{Acknowledgements}

The authors gratefully acknowledge the support by the project Nanobiowat (TE01020218) of the Technology Agency of the Czech Republic.

\section{References}

[1] Vo-Dinh T, Fetzer J, Campiglia AD. Monitoring and characterization of polyaromatic compounds in the nvironm nt. Talanta. 1998;47:943-69. DOI: 10.1016/S0039-9140(98)00162-3.

[2] US EPA O. Resources and Guidance Documents for Compliance Monitoring. US EPA. 2013. Available from: https://www.epa.gov/compliance/resources-and-guidance-documents-compliance-monitoring.

[3] Council Directive 75/440/EEC. European Environment Agency. Available from: https://www.eea.europa.eu/policy-documents/council-directive-75-440-eec.

[4] Council Directive 79/869/EEC. Available from: http://rod.eionet.europa.eu/instruments/213.

[5] Council Directive 80/778/EEC. Available from: https://rod.eionet.europa.eu/instruments/218.

[6] Official Journal of the European Union - L:1998:330:TOC. Available from: https://eur-lex.europa.eu/oj/direct-access.html.

[7] Korzeniowska J, Panek E. Trace metal concentrations in Pleurozium schreberi and Taraxacum officinale along the road No. 7. Ecol Ch $\square$ Eng S. 2019;26:651-63. DOI: 10.1515/eces-2019-0047.

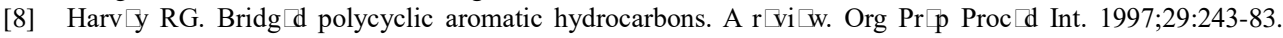
DOI: $10.1080 / 00304949709355197$.

[9] Council Directive 79/869/EEC of 9 October 1979 concerning the methods of measurement and frequencies of sampling and analysis of surface water intended for the abstraction of drinking water in the Member 
States. vol. OJ L. 1979. Available from: https://op.europa.eu/cs/publication-detail/-/publication/af622130de1c-405e-bced-d93f3fc6de64/language-en.

[10] Norin M, Strömvaix AM. Leaching of organic contaminants from storage of reclaimed asphalt pavement. Environ Technol. 2004;25:323-40. DOI: 10.1080/09593330409355466.

[11] Becker L, Matuschek G, Lenoir D, Kettrup A. Leaching behaviour of wood treated with creosote. Chemosphere. 2001;42:301-8. DOI: 10.1016/S0045-6535(00)00071-0.

[12] Pozzoli L, Gilardoni S, Perrone MG, de Gennaro G, de Rienzo M, Vione D. Polycyclic aromatic hydrocarbons in the atmosphere: monitoring, sources, sinks and fate. I: monitoring and sources. Annali Di Chimica. 2004;94(1-2):17-33. DOI: 10.1002/adic.200490002.

[13] Jiang CQ, Alexander R, Kagi RI, Murray AP. Origin of perylene in ancient sediments and its geological significance. Org Geochem. 2000;31:1545-59. DOI: 10.1016/S0146-6380(00)00074-7.

[14] Barrado AI, García S, Castrillejo Y, Barrado E. Exploratory data analysis of PAH, nitro-PAH and hydroxy-PAH concentrations in atmospheric PM10-bound aerosol particles. Correlations with physical and chemical factors. Atmosph Environ. 2013;67:385-93. DOI: 10.1016/j.atmosenv.2012.10.030.

[15] Pachurka L, Gruszecka-Kosowska A, Kobus D, Sowka I. Assessment of inhalational exposure of residents of Wroclaw, Krakow and Warszawa to benzo[a]pyrene. Ecol Chem Eng A. 2018;25:39-49. DOI: 10.2428/ecea.2018.25(1)4.

[16] Mackay D, Shiu WY, Ma KC. Illustrated Handbook of Physical-Chemical Properties of Environmental Fate for Organic Chemicals. Boca Raton, FL: CRC Press; 1997. ISBN: 1566706874

[17] Sverdrup LE, Nielsen T, Krogh PH. Soil ecotoxicity of polycyclic aromatic hydrocarbons in relation to soil sorption, lipophilicity, and water solubility. Environ Sci Technol. 2002;36:2429-35. DOI: 10.1021/es010180s.

[18] Gundel LA, Lee VC, Mahanama KRR, Stevens RK, Daisey JM. Direct determination of the phase distributions of semi-volatile polycyclic aromatic hydrocarbons using annular denuders. Atmosph Environ. 1995;29:1719-33. DOI: 10.1016/1352-2310(94)00366-S.

[19] Chin YP, Aiken GR, Danielsen KM. Binding of pyrene to aquatic and commercial humic substances: the role of molecular weight and aromaticity. Environ Sci Technol. 1997;31:1630-5. DOI: 10.1021/es960404k.

[20] Krauss M, Wilcke W. Predicting soil-water partitioning of polycyclic aromatic hydrocarbons and polychlorinated biphenyls by desorption with methanol-water mixtures at different temperatures. Environ Sci Technol. 2001;35:2319-25. DOI: 10.1021/es001616r.

[21] Organization WH. Guidelines for Drinking-water Quality: Recommendations. World Health Organization; 2004. Available from: https://www.who.int/water_sanitation_health/dwq/GDWQ2004web.pdf.

[22] Fernández P, Carrera G, Grimalt JO, Ventura M, Camarero L, Catalan J, et al. Factors governing the atmospheric deposition of polycyclic aromatic hydrocarbons to remote areas. Environ Sci Technol. 2003;37:3261-7. DOI: 10.1021/es020137k.

[23] Durant JL, Busby WF, Lafleur AL, Penman BW, Crespi CL. Human cell mutagenicity of oxygenated, nitrated and unsubstituted polycyclic aromatic hydrocarbons associated with urban aerosols. Mutation Res/Genetic Toxicol. 1996;371:123-57. DOI: 10.1016/S0165-1218(96)90103-2.

[24] Allen JO, Dookeran NM, Taghizadeh K, Lafleur AL, Smith KA, Sarofim AF. Measurement of oxygenated polycyclic aromatic hydrocarbons associated with a size-segregated urban aerosol. Environ Sci Technol. 1997;31:2064-70. DOI: 10.1021/es960894g.

[25] Rosenkranz HS, Mermelstein R. The genotoxicity, metabolism and carcinogenicity of nitrated polycyclic aromatic hydrocarbons. J Environ Sci Health Part C: Environ Carcinogenesis Rev. 1985;3:221-72. DOI: 10.1080/10590508509373334.

[26] Diamond SA, Milroy NJ, Mattson VR, Heinis LJ, Mount DR. Photoactivated toxicity in amphipods collected from polycyclic aromatic hydrocarbon-contaminated sites. Environ Toxicol Chem. 2009;22:2752-60. DOI: 10.1897/02-640.

[27] Monson PD, Ankley GT, Kosian PA. Phototoxic response of Lumbriculus variegatus to sediments contaminated by polycyclic aromatic hydrocarbons. Environ Toxicol Chem. 1995;14:891-4. DOI: 10.1002/etc.5620140522.

[28] Ankley GT, Collyard SA, Monson PD, Kosian PA. Influence of ultraviolet light on the toxicity of sediments contaminated with polycyclic aromatic hydrocarbons. Environ Toxicol Chem. 1994;13:1791-6. DOI: 10.1002/etc.5620131110.

[29] Ninane L, Kanari N, Criado C, Jeannot C, Evrard O, Neveux N. New Processes for Alkali Ferrate Synthesis. Ferrates, vol. 985. Am Chem Soc; 2008. ISBN: 9780841269613. DOI: 10.1021/bk-2008-0985.ch006.

[30] Alsheyab M, Jiang JQ, Stanford C. Electrochemical generation of ferrate(VI): Determination of optimum conditions. Desalination. 2010;254:175-8. DOI: 10.1016/j.desal.2009.11.035. 
[31] Kudlek E. Identification of degradation by-products of selected pesticides during oxidation and chlorination processes. Ecol Ch $\llbracket \mathrm{m}$ Eng S. 2019;26:571-81. DOI: 10.1515/eces-2019-0042.

[32] Rahdar A, Rahdar S, Ahmadi S, Fu J. Adsorption of ciprofloxacin from aqueous environment by using synthesized nanoceria. Ecol Chem Eng S. 2019;26:299-311. DOI: 10.1515/eces-2019-0021.

[33] Sabliy L, Kuzminskiy Y, Zhukova V, Kozar M, Sobczuk H. New approaches in biological wastewater treatment aimed at removal of organic matter and nutrients. Ecol $\mathrm{Ch} \backsim \mathrm{m}$ Eng S. 2019;26:331-43. DOI: 10.1515/eces-2019-0023.

[34] Wacławek S, Padil VVT, Černík M. Major advances and challenges in heterogeneous catalysis for environmental applications: A review. Ecol Ch $₫ \mathrm{~m}$ Eng S. 2018;25:9-34. DOI: 10.1515/eces-2018-0001.

[35] Vinod VTP, Wacławek S, Senan C, Kupčík J, Pešková K, Černík M, et al. Gum karaya (Sterculia urens) stabilized zero-valent iron nanoparticles: characterization and applications for the removal of chromium and volatil $\square$ organic pollutants from wat $\llbracket$. RSC Adv. 2017;7:13997-4009. DOI: 10.1039/C7RA00464H.

[36] Wacławek S, Silvestri D, Hrabák P, Padil VVT, Torres-Mendieta R, Wacławek M, et al. Chemical oxidation

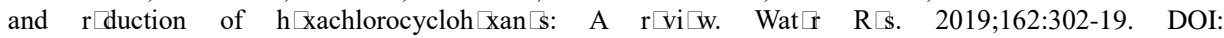
10.1016/j.watres.2019.06.072.

[37] Sharma VK. Potassium ferrate(VI): an environmentally fri \ndly oxidant. Adv Environ R『s. 2002;6:143-56. DOI: 10.1016/S1093-0191(01)00119-8.

[38] Jiang JQ. Advances in the development and application of ferrate(VI) for water and wastewater treatment. $\mathrm{J} \mathrm{Ch} \backsim \mathrm{m}$ T chnol Biot chnol. 2014;89:165-77. DOI: 10.1002/jctb.4214.

[39] Hrabák P, Homolková M, Wacławek S, Černík M. Chemical degradation of PCDD/F in contaminated sediment. Ecol Ch $₫$ Eng S. 2016;23:473-82. DOI: 10.1515/eces-2016-0034.

[40] Walsh FC. Electrochemical technology for environmental treatment and clean energy conversion. Pure Appl $\mathrm{Ch} \backsim$ m. 2001;73:1819-37. DOI: 10.1351/pac200173121819.

[41] Jiang JQ, Lloyd B. Progress in the development and use of ferrate(VI) salt as an oxidant and coagulant for

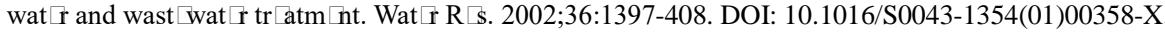

[42] Systém $\square$ vid $\llbracket c$ $\square$ kontaminovaných míst » SEKM. Available from: http://www.sekm.cz/.

[43] Licht S, Naschitz V, Halperin L, Halperin N, Lin L, Chen J, et al. Analysis of ferrate(VI) compounds and super-iron Fe(VI) battery cathodes: FTIR, ICP, titrimetric, XRD, UV/VIS, and electrochemical charact rization. J Pow $\square$ S Sourc. 2001;101:167-76. DOI: 10.1016/S0378-7753(01)00786-8.

[44] Patra D. Applications and new developments in fluorescence spectroscopic techniques for the analysis of polycyclic aromatic hydrocarbons. Appl Sp ctrosc R『v. 2003;38:155-85. DOI: 10.1081/ASR-120021166.

[45] Douglas GS, McCarthy KJ, Dahlen DT, Seavey JA, Steinhauer WG, Prince RC, et al. The use of

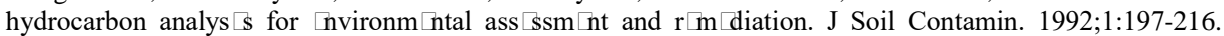
DOI: $10.1080 / 15320389209383411$.

[46] Boehm PD. 15 - Polycyclic Aromatic Hydrocarbons (PAHs). In: Morrison RD, Murphy BL, editors. Environmental Forensics, Burlington: Acad $\square$ mic Pr $\ s$; 1964. DOI: 10.1016/B978-012507751-4/50037-9.

[47] Sharma VK. Disinfection performance of Fe(VI) in water and wastewater: a review. Water Sci Technol. 2007;55:225-32. DOI: 10.2166/wst.2007.019.

[48] 40 CFR 141.61 - Maximum contaminant levels for organic contaminants. USEPA, National Primary Drinking Water Regulations. 2002. Available from: https://www.law.cornell.edu/cfr/text/40/141.61.

[49] Sharma VK, Kazama F, Jiangyong H, Ray AK. Ferrates (iron(VI) and iron(V)): Environmentally friendly

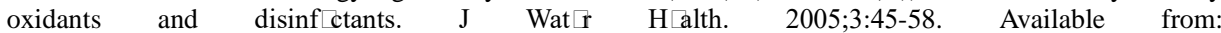
https://pubmed.ncbi.nlm.nih.gov/15952452/

[50] Yunho L, Cho M, Kim YJ, Yoon J. Chemistry of ferrate (Fe(VI)) in aqueouus solution and its applications as a green chemical. J Ind Eng Ch $\square$. 2004;10:161-171. Available from: https://www.cheric.org/research/tech/periodicals/view.php?seq=441272.

[51] Baldantoni D, Morelli R, Bellino A, Prati MV, Alfani A, De Nicola F. Anthracene and benzo(a)pyrene degradation in soil is favoured by compost amendment: Perspectives for a bioremediation approach. J Hazard Mat $\llbracket$ r. 2017;339:395-400. DOI: 10.1016/j.jhazmat.2017.06.043.

[52] Cerniglia CE. Biodegradation of Polycyclic Aromatic Hydrocarbons. Microorganisms to Combat Pollution. Dordr cht: Spring r; 1992. DOI: 10.1007/978-94-011-1672-5_16.

[53] Liao X, Zhao D, Yan X, Huling SG. Identification of persulfate oxidation products of polycyclic aromatic hydrocarbon during $\mathrm{r} \backsim \mathrm{m}$ diation of contaminat $₫$ soil. $\mathrm{J}$ Hazard Mat $\mathrm{r}$. 2014;276:26-34. DOI: 10.1016/j.jhazmat.2014.05.018. 